\title{
Leapfrog Technologies: Can Mobile Technologies Compete Successfully With Traditional Learning Management Systems?
}

\author{
William K. Koomson \\ Associate Professor, Centre for Adult and Distance Education \\ Valley View University, Ghana
}

\begin{abstract}
The objective of this paper was to create an ontology to demonstrate new approaches to study and understand mobile learning through the use of WhatsApp Messenger as a learning tool in a distance learning program. The goal was to add to the body of research and further study how mobile learning can help to remedy the limitations online learning poses for students who live in the sub-Saharan Africa Region with lack of access to electrical power and internet connectivity issues. Qualitative approach was employed with a total sample size of 807 students, composed of 58 percent male and 42 percent female. In designing the blended mobile learning structure, I applied agile methodologies using WhatsApp Messenger as a learning platform, that meets the current infrastructural conditions in Ghana. In this study, I made several assertions that, for WhatsApp to work properly in any classroom in Ghana, there must be intentional designs and step-by-step approach to teach both the faculty and the students how to use the application to achieve the utmost outcomes.
\end{abstract}

Key words: Blended m-Learning, Connectivity, Mobile-Learning, WhatsApp Messenger

\section{INTRODUCTION}

Prior to the advent of mobile phones, many sub-Saharan African countries whose citizens lived in the most remote parts of the country were cut-off regarding the use of telephones, powered by landlines to connect to the global world. However, the abundance of the mobile network systems has changed the face of telecommunication and has transformed the way business is transacted in sub-Saharan Africa and the rest of the developing world. Citizens are able to skip the landline developmental stage of telecommunication to digitalization. Mobile technologies with cellular connectivity continue to dominate the information communication technology market in sub-Saharan Africa. According to the Pew Research Center (2015), cell phone usage in Africa pales in comparison to that of developed countries like the United States of America. However, there has been a dramatic surge in the growth of smartphone usage in sub-Saharan Africa. As of 2014, the following countries recorded high percentages of cell phone usage; Uganda 65\%, Tanzania 73\%, Kenya 82\%, Ghana 83\%, and South Africa, 89\%. In the same year, the United States' cell phone usage was $89 \%$, the same as in South Africa and only in singledigits, higher than Ghana and Kenya. Among the many usages of cell phones in Africa for a twelve-month period, texting was the most commonly used of cell phones (see fig. 1). 


\section{Most Common Use of Cell Phones in Africa}

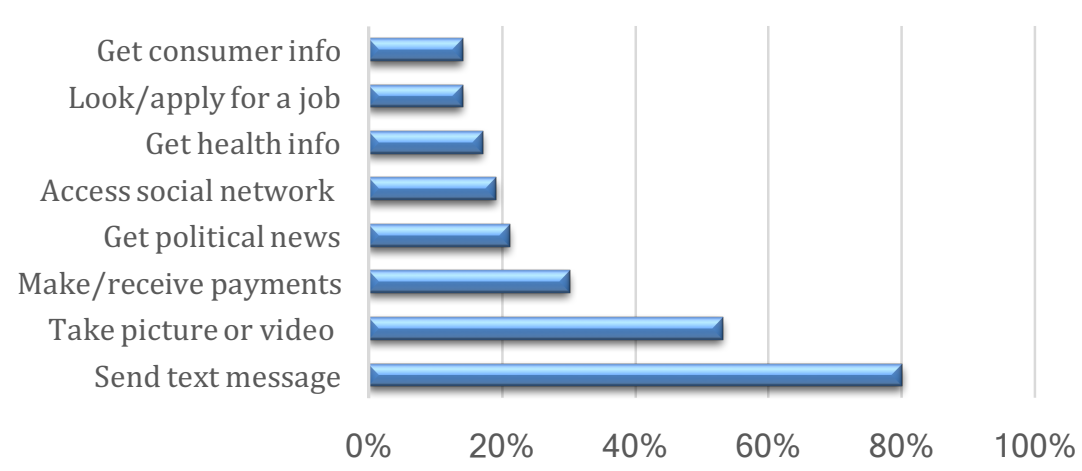

Figure 1: Pew Research Center: Spring 2014 Global Attitudes survey. Q74a-h

The evolution of the Third Generation Web (Web 3.0) and smartphone applications which have been created to run on mobile devices of the $21^{\text {st }}$ Century have transformed the entire universe in all areas, including the way we communicate, function, in our daily living, and even the way we study. Almost every corner of the universe, including developing countries such as, subSaharan Africa, South Asia, and South America, use these technologies for transactional purposes. Farmers use these applications (apps) to transact farm businesses; communities use them to preserve family traditions and memories; and business executives are able to bridge transactional gaps. Meanwhile, researchers acquire access to research artifacts through Mobile Apps, and teachers engage their students in the classrooms using these innovative technologies. Mobile technologies have enabled learning in multiple ways, "people can use mobile devices to access educational resources, connect with others, or create content, both inside and outside classrooms. Mobile learning also encompasses efforts to support broad educational goals such as the effective administration of school systems and improved communication between schools and families" (UNESCO, 2013 p. 6).

Quin (2001) define mobile learning as learning that is done through mobile computational devices, such as "Palms, Windows CE machines, even your digital cell phone." UNESCO has compiled many unique benefits of mobile learning. Among the list are:

1. Reach and equity of education. Mobile technologies provide an excellent medium for extending educational opportunities to learners who may not have access to highquality schooling; they are common even in areas where schools, books and computers are scarce; as the price of mobile phone ownership also continues to decline.

2. Personalized learning. Mobile phones are owned by their users and are carried throughout the day; learners can carry their mobile devices to and from work, school, bedroom, boardroom, and to recreational venues; they are relatively inexpensive; desktop and laptop computers are not portable. Mobile phone and digital devices, by virtue of being highly portable and relatively inexpensive, have expanded the potential and practicability of personalized learning.

3. Provides immediate feedback and assessment. Mobile technologies can streamline assessments and provide learners and teachers more immediate indicators of progress; provide instant feedback; this allows learners to quickly pinpoint problems of understanding and review explanations of key concepts. Mobile applications make it easy for teachers to administer short quizzes to ensure that learners completed a given reading assignment.

4. Productive use of time spent in classroom. When learners utilize mobile technology to complete passive or rote tasks such as listening to a lecture or memorizing information at home, they have more time to discuss ideas, share alternative 
interpretations, work collaboratively, and participate in laboratory activities at school and other learning centers.

5. Build new communities of learners. Mobile devices are used to create communities of learners where they did not exist before. Women network to assist people in their local communities; focused job training to students with similar vocational interests; students pose and answer questions, complete collaborative projects, and engage in the social interactions foundational to learning.

6. Support situated learning. Mobile devices can move learning to settings that maximize understanding. Just as museums regularly offer 'audio guides' that allow visitors to learn about particular artefacts or works of art while viewing them in three dimensions, pioneering developers have made similar 'site-specific' mobile applications to facilitate learning in disciplines as varied as history and chemistry. Mobile devices can, in essence, give literal meaning to the maxim 'the world is a classroom.'

7. Enhance seamless learning. Cloud computing and storage provide students continuous and up-to-date learning experiences regardless of the hardware they use to access content. Because educational resources and information about a learner's progress are stored on remote servers rather than on the hard drive of a single device, students can access similar material from a wide variety of devices (including desktop computers, laptops, tablets and mobile phones), utilizing the comparative advantages of each.

8. Bridge formal and informal learning. Mobile devices facilitate learning by blurring boundaries between formal and informal education. Using a mobile device, students can easily access supplementary materials in order to clarify ideas introduced by a classroom instructor.

9. Minimize educational disruption in conflict and disaster areas. Mobile infrastructure is generally easier and quicker to repair following a disaster or conflict. Mobile learning holds special application for learners living in post-crisis areas.

10. Assist leaners with disabilities. Mobile devices can dramatically improve the learning of students with physical disabilities, in resource-poor and resource-rich communities alike through text-enlargement, voice-transcription, location-aware and text-to-speech technologies.

11. Improve communication and administration. Mobile devices are generally faster, more reliable, cheaper, and more efficient than alternative forms of communication. Learners and educators are increasingly using them to facilitate the exchange of information. In addition, a number of projects active in Asia, Africa and North America rely on mobile phones to streamline communication between classroom instructors who teach similar disciplines or groups of students.

12. Maximize cost-efficiency. Many governments have successfully expanded educational opportunities by leveraging the technology people already own, rather than providing new devices. Initiatives that transform ubiquitous mobile devices into tools for learning, while ensuring equity of opportunity for students who cannot afford them, generally provide affordable solutions to educational challenges (UNESCO, 2013, p. 10-26).

M-learning is a subset of e-learning, which is a subset of distance learning, and distance learning is a subset of flexible learning. According to Brown (2003), flexible learning is divided into distance learning and contact learning (see figure 2). 


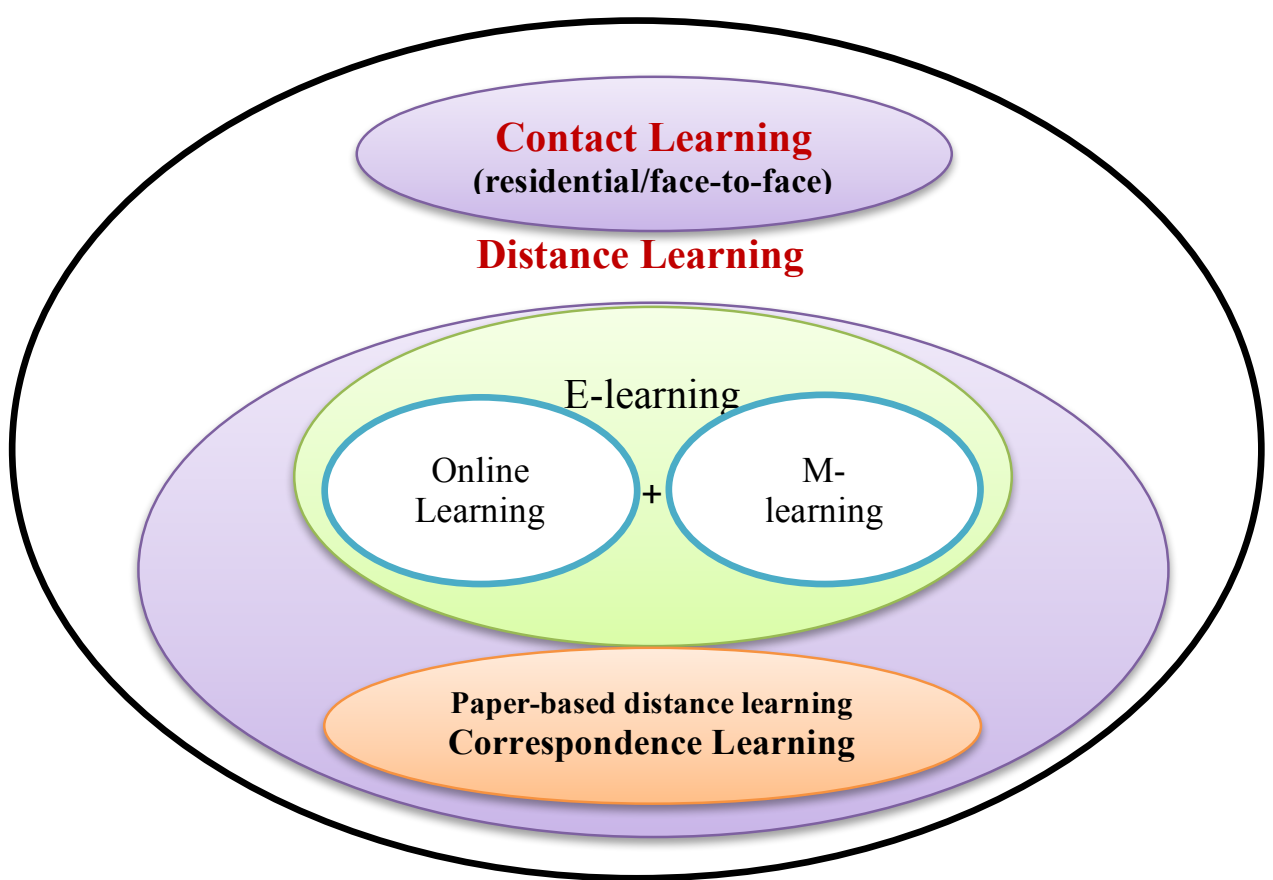

Figure 2: Flexible Learning = (Contact Learning + Distance Learning): Adopted from T. H. Brown, 2003. The subset of flexible learning.

Shearer (2011) posited that, the " $m$ " for mobile learning stands for "on the move." When the "learning" is added, it becomes "knowledge on the move." That is, electronic devices that are portable, always on, and can access the Web anytime and anywhere (Tella, 2003). The idea of mobile learning is narrower and focused on the use of smartphones or tablets. "Taking this narrower view allows us to focus on what we can provide learners in a just-in-time type of experience to supplement their courses" (p., 5).

\section{RELATED WORK}

The objective of this paper was to create an ontology to demonstrate new approaches to study and understand mobile learning through the use of WhatsApp Messenger as a learning tool in a distance learning program. The goal was to add to the body of research and further study how mobile learning can help to remedy the limitations online learning poses for students who live in sub-Saharan Africa with lack of access to electrical power and internet connectivity issues. Motlik (2008) suggested that, mobile learning will pave the way for online learning as the internet is not stable and is unavailable in many parts of rural areas in developing nations. Also mobile learning is more affordable to less developed nations and financially constrained groups (Gronlund \& Islam, 2010).

Notwithstanding these positive developments, some, including academics in higher education in sub-Saharan Africa, refuse to accept the fact that online learning can be done through mobile devices. They still believe that because of the unstableness of Internet connectivity, few institutions of formal learning can successfully go online in sub-Saharan Africa, including Ghana (Yeboah \& Ewur, 2014). However, with mobile learning technologies like "WhatsApp Messenger," developing countries have no excuses as to why they are not able to adopt online learning in the remotest parts of the country where connectivity is a major setback. Everywhere a mobile phone is used, whether for WhatsApp, Email, SMS, video or photo sharing, online learning is possible. In the academic environments, just as in the community, households and business places, WhatsApp Messenger has been used to create group chats for work teams, social networking, and learning. 
In Ghana, the most common format adopted in Distance Learning is the tutorial format, where very few online interactions occur; in most instances, there are no online interactions. The universities that enroll their students through the distance learning mode, rely heavily on print materials in the form of course modules and students meet regularly during weekends in tutorial centers throughout the nation where they receive face-to-face instructions. Very few programs include videos and voice presentations in their distance learning pedagogy (Larkai, AnkomahAsare, \& Nsowah-Nuamah, 2016; Yeboah \& Ewur, 2014).

\section{WhatsApp Messenger for m-Learning}

Research on the application of WhatsApp Messenger in the classroom is new and developing, however, its usage as a social media tool on smartphones is widespread (Cetinkaya, 2017; Bouhnik \& Deshen, 2014; Yeboah \& Ewur, 2014; Church \& de-Oliviera, 2013). WhatsApp is the most popular mobile messaging application widely used worldwide and is ranked as the number one in terms of monthly active users, based on a study of over 22,500 sources worldwide (Statista, 2018).

WhatsApp features include;

- Text - simple and reliable;

- Group Chat - keeping in touch with love ones, people in your network, business partners, and parishioners;

- On the Web and Desktop - keeping the conversation going anytime, anyplace, anywhere;

- Voice and Video Calls - free face-to-face conversation, when voice and text are not enough;

- End-to-End Encryption - provides security by default;

- Photos and Videos - opportunity to share moments that matter;

- Voice Messaging - using the voice messaging system to convey emotional moments; and

- Documents - attaching and sharing documents including PDFs, spreadsheets, slideshows, photos, and Word documents (http://www.whatsapp.com/features/).

WhatsApp Messenger features make it easy for teaching and learning. The app uses phone internet connections (4G/3G/2G/EDGE of Wi-Fi) of users to send and receive messages. That is, as long as there is data on users' phones, sending and receiving messages are free. (https://faq. whatsapp.com/en/android/20965922/). WhatsApp announced in May 2018 at its F8 developer conference in San Jose, California, that over 65 billion messages have been sent by users with more than 2 billion minutes of voice and video calls made everyday on the app platform, and about 1 billion people uses this messaging app each day (Al-Heeti, 2018). Though few studies have researched into the educational benefits of the WhatsApp Messenger platform; students at the university level have used the texting feature to send and receive short messages through mobile devices; institutions of higher learning are gradually adopting WhatsApp for educational purposes; and discussion forums that are prominent in Learning Management Systems (LMS) are also available on some mobile learning platforms such as WhatsApp Messenger (Chan, 2005; Johnson, 2007, Smith, Salaway, \& Caruso, 2009).

\section{Key Players of the Ontology}

Factors that plague online learners in Ghana are many, including; computer illiteracy, access, long-term power outages, and connectivity. Relevant skills deficiency hinders successful facilitation of online learning through discussion boards, timely response to students, and promotion of active learning strategies. "Online instructors specifically need to be able to facilitate online discussions that are rich and meaningful, respond in a timely manner, and 
model active learning strategies" (Burns, 2011 p. 87). However, universities in Ghana lack the appropriate infrastructure to offer courses online, thereby resorting to face-to-face tutorial sessions in the form of tutorial center operations throughout the country by using untrained tutors who have little or no experience in distance learning. Students who are enrolled in the distance learning programs have to attend tutorials every weekend or bi-weekly.

According to Kent Löfgren's (2013) introduction to the word and the concept of ontology, the word ontology is used in two different contexts; philosophical and non-philosophical. At the philosophical context, the word is used to study what is real and what exist. However, at the non-philosophical context, Löfgren explained that the word is used more narrowly to describe what exists within a determined field. He further posited that, under the non-philosophical context, researchers focus on identifying important key players in a particular field and investigate the inter-relationships that brings them together (Carson, Gilmore, Perry, \& Gronhaug, 2001; Barry, 1992; Löfgren, 2013). For example, an effective distance learning program requires inter-relationships among key players. This section identifies four important key players, which include: students, faculty, support staff, and administrators (Barry, 1992):

Students' engagement in an online learning has taken a new shape. Brian Kathman (2017) posited that, higher education institutions are engaging students more and more through text messaging and fostering of one-to-one relationships. In the past, distance learning students were not as able to freely interact with each other to share their backgrounds and interests. However, new technologies are bringing students together and helping to build communities of learners through distance education (Barry, 1992, pp. 30-32).

The success of an effective distance education program depends on the faculty. Bernard Bull (2013), list eight roles of an effective online teacher as follows;

a) The tour guide - "the teacher directs and redirects the attention of learners toward key concepts and ideas. A good tour guide doesn't want anyone to miss out on the highlights of the tour;"

b) The cheerleader - "at times, learners may fall into negative comments about themselves, the class, or their classmates. The cheerleader strives to find ways to listen, respect the learner's frustrations, but to also help them reframe the situation in ways that are more positive and productive;"

c) Learning coach - a skilful teacher "moves beyond simply modelling a love for the subject and personal skill with the content. Instead, finds ways to hand the subject over to the students to do something with it;"

d) Individual and group mirror - just like looking into the mirror in the morning to see what is sticking out on you, "learners need this same sort of feedback about their work. How are they doing? Are they getting closer to meeting the learning objectives or not? The effective online teacher finds ways to give this sort of feedback to individual learners and, when appropriate, groups of learners;"

e) Social butterfly - "the online teacher must serve like a great party host, facilitating introductions, using discussion starters to facilitate conversations among students, and taking the time to get to know students and referencing that knowledge in interactions with them;"

f) Big brother - like a spy of a sort; "the teacher can tell when and how many times a student logs into the course, what pages were viewed or not, how many discussions posts the student contributed, and much more." That is, "if a student is not logging in, then contact the student. If students are failing to visit pages in the course with key instructions, point that out to the students or reorganize the content so that it's easier to find;" 
g) Valve control - "the teacher as valve control intentionally releases content in chunks that are appropriate for students. Sometimes this comes in the form of only releasing content one week at a time. Other times, the teacher releases it all at once, but directs students to only focus on certain parts at a time;"

h) Co-learner - "great teachers are lifelong learners, and they can model that learning for their students in a variety of ways in the online classroom. The teacher can be an active (but not too active or it will silence students) participant in online discussions, sharing what they are learning about the subject, and even complete all or parts of some assignments, sharing their work with the students" (www.facultyfocus.com).

Barry Willis (1992) described the support staff as "silent heroes of a successful distance education program" (p. 37). The support staff assist in promoting persistence and participation to avoid students' dropout. Their services include academic, administrative, and technological support. In most institutions, the support staffs' services are offered through extended hours (Moisey \& Hughes, 2008).

Administrators are entrusted to ensure that a strategic plan is in place that promotes effective teaching and learning. Their duties include, planning for technological resources, deploying manpower resources, financial and the necessary capital expenditures to enhance the institution's online learning mission. They also "lead and inspire faculty and staff in overcoming obstacles that arise. Most importantly, they maintain an academic focus, realizing that meeting the instructional needs of distant students is their ultimate responsibility" (Barry, 1992, p. 38).

\section{METHODOLOGY}

This paper used qualitative approach, framed under the paradigm which postulates that reality is relative and depends on multiple systems for meaning. On-to-logy, a Greek word, relates to the nature of reality as seen in the lens of a person in his experiences, this experience may lead the individual to seek meaning. There are two schools of thoughts: the objectivist and subjectivist. The objectivist approach correlates with a quantitative research paradigm, while the subjectivist approach sees the world as socially constructed - a qualitative paradigm (Hudson \& Ozanne, 1988; Lincoln \& Guba, 1985; Neuman, 2000).

Qualitative ontological researchers believe that the researcher and the researched are not mutually exclusive and that the context, background, cultural setting, and values of the researcher can influence the observation. Qualitative researchers seek to create theory and new meaning in specific settings, while quantitative researchers test objective theories as they do examine the relationship between and among variables. In a qualitative study, the researcher observes why events occur and what those events mean to the population being studied (Bogdan \& Biklen, 2006; Corbin \& Strauss, 2008; Creswell, 2014).

In a typical university distance learning classroom in Ghana; there are students who come directly from the Senior High Schools (17 to 21 year olds); Top-up students (21 - 27 year olds) coming from the nation's Polytechnics, Colleges of Education, and diploma (or associate) degree programs who enrol into the universities for degree purposes; mature students who are permitted to enrol into university degree programs after attaining the age of 25 (25 - 40 year olds); and similar age groups who are workers and are seeking university degrees for professional advancements. A vast majority of these students live in the nation's hinterlands and are not able to take full advantage of online learning due to factors beyond their control. 
This paper describes an ongoing research study, which began in January 2017, about how to create an effective distance learning program in a hybrid mode that integrates WhatsApp Messenger as the learning platform for students who live in Ghana's remote areas where connectivity and electrical power supply are limited. The purpose was to better understand the application of WhatsApp Messenger by using its features to construct meaning for learners and instructors in an online learning context. The study was based in a university in Ghana with three campuses and two learning centers with total student population of about 10,000. A sampled total of 807 students from three campuses and two learning centres of the university adopted the use of WhatsApp Messenger in a blended online learning mode.

\section{Practical Applications of the Ontology}

The applications of the ontologies for this paper ranged from identifying multiple factors that hindered these key players, to successfully engaging in online learning at the tertiary education level. Online learning is increasingly gaining popularity in higher educational institutions in the world, including developing countries, like Ghana. Notwithstanding its popularity, the fact that online learning must be done using recent technologies and internet connectivity all require some basic computing skills, information communication technology (ICT) skills, and internet access.

The Sloan Consortium (2008), classified online learning as follows: $0 \%=$ Traditional - where course uses no online technology and content is delivered in writing, oral, or audiovisual format; $1-29 \%=$ Web-facilitated - course uses Web-based technology to facilitate what is essentially a face-to-face course and might use learning management system (LMS) to post the syllabus and assignments; $30-79 \%=$ Blended/hybrid - course blends online and face-to-face settings, a substantial proportion of the content is delivered online, and the course typically uses online discussions, but also includes some face-to-face meetings; 80-100\% = Online - course delivers the vast bulk of content online, and course typically has no face-to-face meetings.

Table 1 classifies online learning into different categories: traditional classroom learning, webfacilitated, blended or hybrid, and fully online. The format adopted for the study was blended or hybrid online learning. 
Table 1: Classification of Blended Online Learning

\begin{tabular}{|c|c|c|}
\hline Category & Definition & Applicable to Current Research Context \\
\hline \multicolumn{3}{|c|}{ Course-Level Definitions } \\
\hline $\begin{array}{l}\text { Classroom } \\
\text { Course }\end{array}$ & $\begin{array}{l}\text { Course activity is organized around } \\
\text { scheduled class meetings. No online sessions, } \\
\text { only face-to-face meetings. }\end{array}$ & Regular Mode \\
\hline $\begin{array}{l}\text { Synchronous } \\
\text { Distributed } \\
\text { Course }\end{array}$ & $\begin{array}{l}\text { Web-based technologies are used to extend } \\
\text { classroom lectures and other activities to } \\
\text { students at remote sites in real time. }\end{array}$ & N/A in current research context \\
\hline $\begin{array}{l}\text { Web-Enhanced } \\
\text { Course }\end{array}$ & $\begin{array}{l}\text { Online course activity complements class } \\
\text { sessions without reducing the number of } \\
\text { required class meetings. }\end{array}$ & N/A in current research context \\
\hline $\begin{array}{l}\text { Blended/Hybrid } \\
\text { Classroom } \\
\text { Course }\end{array}$ & $\begin{array}{l}\text { Online activity is mixed with classroom } \\
\text { meetings, replacing a significant percentage, } \\
\text { but not all required face-to-face instructional } \\
\text { activities. }\end{array}$ & $\begin{array}{l}\text { Students meet four times for face-to-face } \\
\text { tutorials with their instructors in a } 10- \\
\text { week Session. Hybrid mode. }\end{array}$ \\
\hline $\begin{array}{l}\text { Blended/Hybrid } \\
\text { Online Course }\end{array}$ & $\begin{array}{l}\text { Most course activity is done online, but there } \\
\text { are some required face-to-face instructional } \\
\text { activities, such as lectures, discussions, labs, } \\
\text { or other in-person learning activities. }\end{array}$ & $\begin{array}{l}\text { Students meet four times for face-to-face } \\
\text { tutorials with their instructors in a } 10- \\
\text { week Session. Hybrid mode. } \\
\text { There are two-weekend meeting for } \\
\text { proctored final examinations. }\end{array}$ \\
\hline Online Course & $\begin{array}{l}\text { All course activity is done online; there are } \\
\text { no required face-to-face sessions within the } \\
\text { course and no requirements for on-campus } \\
\text { activity. }\end{array}$ & N/A in current research context \\
\hline
\end{tabular}

Source: Online Learning Consortium. Sener (2015).

\section{ANALYSIS OF THE ONTOLOGY}

Table 2 consists of demographic characteristics of the sample participants in the study. Total sample size for the study was 807, composed of 58 percent males and 42 percent females. Students above the age of 25 formed the dominant age group for the study, scoring a total of 83 percent. Sixty percent of the students were married with about 44 percent indicating that about 4 persons depend on them for their sustenance. About 51 percent of the students indicated that they entered the university with other qualifications apart from associate degree or high school diploma. Concerning commitment to study, about 89 percent of the students indicated that they work, while about 54 percent of them were engaged in full time employment. Forty-three percent of the students in the study were committed to study for about ten hours a week. 
Table 2: Characteristics of Participants: Mobile Learning Survey Results

\section{Campus Campus Campus}

1

2

3

Centre 1 Centre 2 Total \%

Total

Students

\section{Demographics}

Number of Students

Gender

Male

Female

Age Group

15-19

20-24

$>25$

\section{Marital Status}

Married

Not Married

Class Standing

Freshmen (Level 100)

Sophomore (Level 200)

Junior (Level 300)

Senior (Level 400)

Entry Qualification

Associate Degree (HND*)

High School Certificate

Other**

28
52.
47

\section{7}

\section{8}

42

47.6

2

9

89

58

42

45

12

21

22

42

15

43

\section{8}

53

8

17

75

33

24

13

27

60

52

155

54

0

807

469

338

39

38

43

58.08

41.92

21

1

0

2

2.6

115

85

85

16

14.2

671

$82 \quad 83.2$

486

321

48

77

61

60.2

39.8

278

31

35

$$
28
$$

34.4

184

$$
25
$$

15

22.8

176

20

$$
15
$$

25

21.8

169

30

45
17
38

$$
29
$$

34.6

279

119

52

38

11

14.8

408

\section{Time Commitment}

\section{Dependents***}

1

2-4

$>5$

Work

Yes

No

$\begin{array}{rrrrrrr}26 & 40 & 35 & 38 & 33 & 34.4 & 278 \\ 57 & 38 & 38 & 42 & 45 & 44 & 355 \\ 17 & 22 & 27 & 20 & 22 & 21.6 & 174 \\ 91 & 89 & 92 & 88 & 85 & 89 & 718 \\ 9 & 11 & 8 & 12 & 15 & 11 & 89\end{array}$

Hours Worked/Week

$<20$
$20-30$
$30-40$
$>40$

$\begin{array}{rrrrrrr}13 & 4 & 10 & 15 & 7 & 9.8 & 79 \\ 38 & 32 & 38 & 32 & 40 & 36 & 291 \\ 42 & 57 & 42 & 43 & 35 & 43.8 & 353 \\ 7 & 7 & 10 & 10 & 18 & 10.4 & 84\end{array}$

Hours Allocated for Learning

$<2$

$2-4$

$2 \quad 20 \quad 5$

5

8

8

5-10

\begin{tabular}{rrrrrrr}
50 & 53 & 41 & 42 & 28 & 42.8 & 345 \\
40 & 16 & 24 & 30 & 13 & 24.6 & 199 \\
\hline
\end{tabular}

30

10

9

73

${ }^{*}$ HND - Higher National Diploma is equal to a two-year Associate Degree. These students are enrolled into the BA/BS program as "top-up students.

**Other - students who enroll into the program through the Mature Entrance route. Students must be 25-years old before they qualify

***Dependents - means a spouse of a student/children/parents that are directly supported by the students/ and any other qualified dependent 


\section{Blended Mobile Learning Structure}

I present in Table 3, a mobile learning structure indicating a summary comparison between a typical Learning Management System (LMS) and the proper application of the use of WhatsApp as mobile learning platform in a Ghanaian context.

The following assumptions were made to explain table 3 :

\section{Assumption \# 1}

Why it will not work

a) WhatsApp Messenger as a social media tool is not fit for the classroom - for learning purposes.

b) A typical LMS delivers courseware over the internet - lack of internet connectivity and prolonged power outages in Ghana, especially, in the countryside makes it impossible to sustain online learning. Therefore, LMS will not work for students in Ghana who live far away from the cities.

\section{Assumption \# 2}

How it will work

a) For WhatsApp to function properly in online learning environment, the features must be properly integrated to fit the purpose of teaching and learning in a mobile learning context.

b) WhatsApp Messenger uses phone internet connections of users to send and receive messages. That is, as long as there is data on users' phones, sending and receiving messages are free. Therefore, students in Ghana, who live far away from the cities can also access online learning benefits through their mobile devices.

Jurado, Pattersson, Regueiro-Gomez, and Scheja, (2014), classified learning management systems features into four different tool groups, namely: distribution, communication, interaction, and administration.

1. Tools for distribution allow lecturers to upload documents, available to students. Earlier it was mainly text documents and today it may also be different kinds of media files. Nevertheless, the process is still one-way, that is, teacher-to-learner distribution of information.

2. Tools for communication allow information to go either way as well as from studentto-student. The most common example is E-mail.

3. Tools for interaction call for reaction and feedback. Discussion boards are the most typical example. These tools are of great interest since they may promote student activity and cooperation, hence enhancing the learning experience.

4. Tools for course administration are used to monitor and document the educational process, rather than to facilitate teaching or learning (p.4). 
Table 3. Mobile Learning Structure Using WhatsApp Messenger - Ghanaian Context

\begin{tabular}{|c|c|c|c|c|}
\hline $\begin{array}{l}\text { Application: } \\
\text { Online learning } \\
\text { tools. Jurado, et } \\
\text { al., (2014) }\end{array}$ & $\begin{array}{l}\text { Key Players: } \\
\text { Students/faculty/ } \\
\text { support staff/ } \\
\text { administrators }\end{array}$ & $\begin{array}{l}\text { Purpose: } \\
\text { Teaching and } \\
\text { learning using } \\
\text { blended mode of } \\
\text { online learning }\end{array}$ & $\begin{array}{l}\text { Learning Management } \\
\text { System (LMS): } \\
\text { Why LMS will not work } \\
\text { in Ghana due to lack of } \\
\text { Internet Access }\end{array}$ & $\begin{array}{l}\text { WhatsApp Messenger for } \\
\text { Learning: } \\
\text { How WhatsApp will work } \\
\text { despite lack of Internet Access } \\
\text { in Ghana }\end{array}$ \\
\hline Distribution & $\begin{array}{l}\text { 1. Faculty } \\
\text { 2. Student } \\
\text { Interaction flows } \\
\text { from teacher to } \\
\text { student }\end{array}$ & $\begin{array}{l}\text { One-way: from } \\
\text { teacher to } \\
\text { student - one } \\
\text { way process }\end{array}$ & 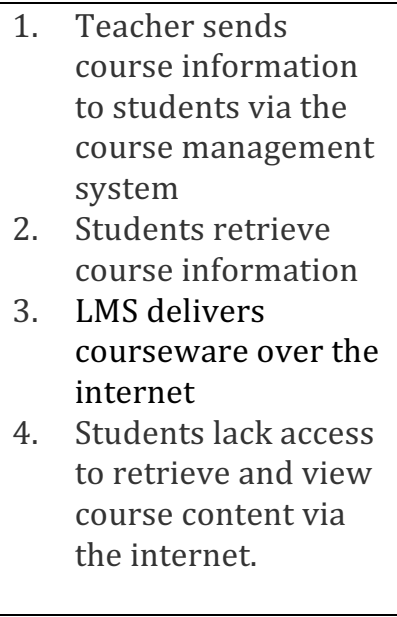 & 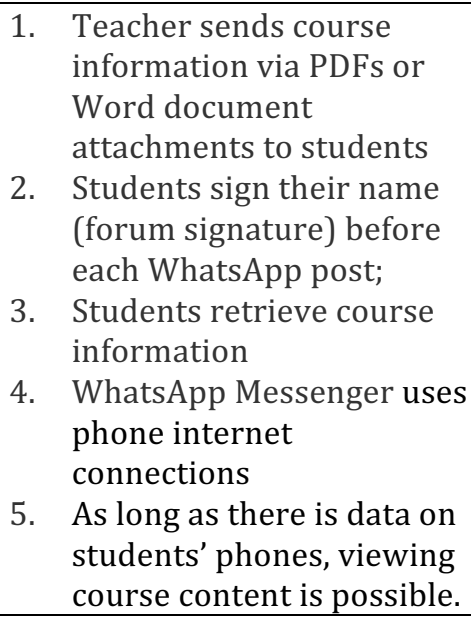 \\
\hline Communication & $\begin{array}{l}\text { 1. Faculty } \\
\text { 2. Student } \\
\text { Interaction flows } \\
\text { both ways }\end{array}$ & $\begin{array}{l}\text { Information go } \\
\text { either way. } \\
\text { Teacher to } \\
\text { student, student } \\
\text { to teacher }\end{array}$ & $\begin{array}{l}\text { 1. Students respond to } \\
\text { teacher via the } \\
\text { course management } \\
\text { system } \\
\text { 2. Teacher grades } \\
\text { students work and } \\
\text { post comments on } \\
\text { course management } \\
\text { system }\end{array}$ & $\begin{array}{l}\text { 1. Students post completed } \\
\text { assignments in more than } \\
\text { one format via: } \\
\text { a. PDF or Word } \\
\text { attachments } \\
\text { b. Direct text } \\
\text { message } \\
\text { 2. Teacher grades students } \\
\text { work and post comments } \\
\text { via WhatsApp Messenger } \\
\text { 3. Teacher sends transcripts } \\
\text { of WhatsApp } \\
\text { communication to course } \\
\text { administrators. }\end{array}$ \\
\hline Interaction & $\begin{array}{l}\text { 1. Students } \\
\text { Peer interactions. } \\
\text { Student to student }\end{array}$ & $\begin{array}{l}\text { Discussion } \\
\text { boards, students } \\
\text { reactions and } \\
\text { feedbacks. }\end{array}$ & $\begin{array}{l}\text { 1. Student to student } \\
\text { interaction through } \\
\text { LMS discussion } \\
\text { forums } \\
\text { 2. Teacher as facilitator } \\
\text { guides students }\end{array}$ & $\begin{array}{l}\text { 1. Students to student } \\
\text { interaction through: } \\
\text { a. WhatsApp 'group- } \\
\text { chat' } \\
\text { b. Possible video and } \\
\quad \text { voice calls } \\
\text { 2. Teacher as facilitator } \\
\text { guides students }\end{array}$ \\
\hline $\begin{array}{l}\text { Course } \\
\text { Administration }\end{array}$ & $\begin{array}{l}\text { 1. Support Staff } \\
\text { 2. Administrators } \\
\text { Back-end } \\
\text { interaction }\end{array}$ & $\begin{array}{l}\text { Course } \\
\text { monitoring, } \\
\text { management, } \\
\text { documentation, } \\
\text { and evaluation. }\end{array}$ & $\begin{array}{ll}\text { 1. } & \text { Teacher setup the } \\
\text { courses via the LMS } \\
\text { 2. } \\
\text { Teacher post course } \\
\text { syllabus and } \\
\text { assignments for } \\
\text { class discussions } \\
\text { 3. Teacher grades } \\
\text { students work and } \\
\text { post grades online } \\
\text { 4. Students perform } \\
\text { teacher and course } \\
\text { evaluations online }\end{array}$ & $\begin{array}{ll}\text { 1. } & \text { Support staffs create } \\
& \text { WhatsApp groups for } \\
& \text { students and faculty } \\
\text { 2. } & \text { Support staff monitors } \\
\text { students and faculty } \\
\text { interactions through } \\
\text { WhatsApp transcripts } \\
\text { 3. } & \text { Support staff receives } \\
\text { transcripts from teachers } \\
\text { regularly and monitors for } \\
\text { course content and } \\
\text { interactions } \\
\text { 4. Teacher sends WhatsApp } \\
\text { transcripts to program } \\
\text { office for archival purposes. } \\
\text { 5. Support staff archives } \\
\text { course materials for quality } \\
\text { control purposes. }\end{array}$ \\
\hline
\end{tabular}


Table 4 describes how students preferred the use of the WhatsApp Messenger in a blended mobile learning due to ease of use, convenience, cost, and accessibility.

Table 4: Results from Selected Campuses/Centre Surveys: Social Media and Mobile Learning

\begin{tabular}{|c|c|c|c|c|}
\hline SURVEY QUESTIONS & Campus 1 & Campus 2 & Centre 1 & MOSTLY CHECKED ITEM \\
\hline $\begin{array}{l}\text { 1. Which communication method do you } \\
\text { prefer for social and business } \\
\text { networking? Please check all that apply. }\end{array}$ & $\begin{array}{l}\text { Phone calls; } \\
\text { WhatsApp; } \\
\text { Email }\end{array}$ & $\begin{array}{l}\text { Phone calls; } \\
\text { WhatsApp; } \\
\text { Email }\end{array}$ & $\begin{array}{l}\text { Phone calls; } \\
\text { WhatsApp; } \\
\text { Email }\end{array}$ & $\begin{array}{l}\text { Phone calls; WhatsApp; } \\
\text { Email; and Facebook }\end{array}$ \\
\hline 2. Do you own a mobile phone? & $100 \%=$ Yes & $100 \%=$ Yes & $100 \%=$ Yes & Everyone answered Yes \\
\hline $\begin{array}{l}\text { 3. How often do you have your mobile } \\
\text { phone with you? }\end{array}$ & $\begin{array}{l}100 \%= \\
\text { Always }\end{array}$ & $\begin{array}{l}100 \%= \\
\text { Always }\end{array}$ & $\begin{array}{l}66 \%=\text { Always } \\
34 \%= \\
\text { Sometimes }\end{array}$ & $\begin{array}{l}\text { Students keep phones } \\
\text { Always }\end{array}$ \\
\hline $\begin{array}{l}\text { 6. Which activities do you most often } \\
\text { engage in on your mobile phone? Please } \\
\text { check all that apply. }\end{array}$ & $\begin{array}{l}\text { Phone calls; } \\
\text { WhatsApp; } \\
\text { Facebook }\end{array}$ & $\begin{array}{l}\text { Phone calls; } \\
\text { WhatsApp; } \\
\text { Facebook }\end{array}$ & $\begin{array}{l}\text { Phone calls; } \\
\text { WhatsApp; } \\
\text { Facebook }\end{array}$ & $\begin{array}{l}\text { Phone calls; WhatsApp; } \\
\text { Facebook; Email }\end{array}$ \\
\hline $\begin{array}{l}\text { 7. Would you be comfortable allowing your } \\
\text { lecturer to contact you through your } \\
\text { mobile phone? }\end{array}$ & $100 \%=$ Yes & $95 \%=$ Yes & $100 \%=$ Yes & $\begin{array}{l}\text { Students will Allow } \\
\text { lecturer contact thru cell } \\
\text { phones }\end{array}$ \\
\hline $\begin{array}{l}\text { 8. Would you be comfortable receiving your } \\
\text { grade report through text messaging? }\end{array}$ & $100 \%=$ Yes & $98 \%=$ Yes & $68 \%=$ Yes & $\begin{array}{l}\text { Students are ok } \\
\text { receiving grade report } \\
\text { thru text }\end{array}$ \\
\hline $\begin{array}{l}\text { 9. Would you agree that having course } \\
\text { materials such as lecture notes, practice } \\
\text { quizzes, videos, and PowerPoints } \\
\text { available on your mobile phone would be } \\
\text { beneficial to your study process? }\end{array}$ & $100 \%=$ Agree & $90 \%=$ Agree & $100 \%=$ Yes & $\begin{array}{l}\text { Students prefer course } \\
\text { materials available thru } \\
\text { mobile phones }\end{array}$ \\
\hline
\end{tabular}

*(Selected Campuses/Centre with more than 100 students)

When the question was asked about students' willingness to purchase a new mobile device if they thought it would improve their performance at school; 87 percent indicated "yes." All the students indicated that having course materials such as lecture notes, practice quizzes, videos, and PowerPoints available on their mobile phones would be beneficial for their study process. Students indicated that they would be comfortable to allow their lectures to contact them through their mobile phones. When the question was asked that "which communication method do you prefer for social and business networking?" Students checked phone calls as number one, followed by WhatsApp Messenger. Students also indicated that, apart from using their mobile phones to make and receive calls, WhatsApp texting was the activities they often engaged in with their mobile phones. 


\section{Discussion}

\section{DISCUSSION AND CONCLUSION}

This paper depicted an ontology of an ongoing research study. The purpose of the research was to better understand the application of WhatsApp Messenger by using its features to construct meaning for learners and instructors in a blended mobile online learning context. The study was based in a university in Ghana with three campuses and two learning centers with total student population of about 10,000. A sampled total of 807 students from three campuses and two learning centres of the university adopted the use of WhatsApp Messenger in a blended online learning mode. Total sample size for the study was 807, composed of 58 percent male and 42 percent female. Students above the age of 25 formed the dominant age group for the study, scoring a total of 83 percent. Sixty percent of the students were married with about 44 percent indicating that about 4 persons depend on them for their sustenance. About 51 percent of the students indicated that they entered the university with other qualifications apart from associate degree or high school diploma.

Concerning commitment to study, about 89 percent of the students indicated that they work, while about 54 percent of them were engaged in full time employment. Forty-three percent of the students in the study were committed to study for about ten hours a week. The results from the demographics report fit traditional adult learners as described in the literature. According to Ross-Gordon (2011), adult students, referred to as - non-traditional students form sizeable presence on university campuses and also constitute a substantial share of the undergraduate student body. The National Center for Educational Statistics (NCES, 2009) survey reported that 38 percent of student enrolment for the 2007 academic year were 25 years of age or older. Choy (2002) cited the 2002 NCES statistics that defined seven characteristics of non-traditional students as follows:

1. Entry to college delayed by at least one year following high school,

2. Having dependents,

3. Being a single parent,

4. Being employed full time,

5. Being financially independent,

6. Attending part time, and

7. Not having a high school diploma.

Ross-Gordon (2011) described characteristics that separate re-entry adults from other traditional university students to be; "the high likelihood that they are juggling other life roles while attending school, including those of worker, spouse or partner, parent, caregiver, and community member" (p. 27).

\section{Conclusion}

In designing the blended mobile learning structure, I applied agile methodologies using WhatsApp Messenger as a learning platform, that meets the current infrastructural conditions in Ghana. Seth Earley (2017), stated that, there must be the need to interpret user signals accurately to "enable the system to present the right content for the user's context," this may "require not only that our customer data is clean, properly structured, and integrated across multiple systems and processes but also that the system understand the relationship between the user, his or her specific task, the product, and the content needed" (pp. 58-64).

According to Yeboah and Ewur (2014), the adoption of WhatsApp in the classroom is anathema. To them, the technology is nuisance to university students. They concluded that, "if students bring their mobile phones to class, they get bored of the lesson and find their way onto WhatsApp. These detracts their attention from the main lesson, and are not able to fully 
understand what is going on, hindering participation and drawing them even further into WhatsApp making it more difficult for them at the end of the day" (p. 162).

Contrary to Yeboah and Ewur's, assertions, the current paper has proven otherwise. In this study, I made several assertions that, for WhatsApp to work properly in any classroom in Ghana, there must be intentional designs and step-by-step approach to teach both the faculty and the students how to use the application to achieve the utmost outcomes (see table 4, above). Because, I believe that, "seemingly intractable problems have been solved by advances in processing power and capabilities. Not long ago, autonomous vehicles were considered technologically infeasible due to the volume of data that needed to be processed in real time. Speech recognition was unreliable and required extensive speaker-dependent training sessions. Mobile phones were once "auto-mobile" phones, requiring a car trunk full of equipment" (Earley, 2017, pp. 58-64).

\section{References}

Al-Heeti, A. (2018). WhatsApp: 65B messages sent each day, and more than $2 B$ minutes of calls. C/net News. Retrieved on July 14, 2018, from: https://www.cnet.com/news/whatsapp-65-billion-messages-sent-each-dayand-more-than-2-billion-minutes-of-calls/

Barry, W. (1992). Effective distance education: A primer for faculty and administrators. Monograph Series in Distance Education No. 2. Fairbanks, Alaska.

Bogdan, R. \& Biklen, S.K. (2006). Qualitative Research for Education: An Introduction to Theories and Methods. 5th ed. London, UK: Pearson.

Bouhnik, D. \& Deshen, M. (2014). Whatsapp goes to school: Mobile instant messaging between teachers and students. Journal of Information Technology Education: Research, 13:217-231.

Brown, T. H. (2003, June). The role of m-learning in the future of e-learning in Africa? Presented at the 21st ICDE World Conference, Hong Kong, China. Retrieved from: http://www.tml.tkk.fi/Opinnot/T-

110.556/2004/Materiaali/brown03.pdf

Bull, B. (2013). Eight roles of an effective online teacher. Higher Education Teaching Strategies from Magna Publications: Faculty Focus. Retrieved on July 18, 2018, from: https://www.facultyfocus.com/articles/onlineeducation/eight-roles-of-an-effective-online-teacher/

Burns, M. (2011). Distance education for teacher training: Modes, models, and methods. Education Development Center Inc. Washington, DC.

Carson, D., Gilmore, A., Perry, C., \& Gronhaug, K. (2001). Qualitative Marketing Research. London: Sage.

Cetinkaya, L. (2017). The impact of WhatsApp use on success in education process. The International Review of Research in Open and Distributed Learning. 18(7). 10.19173/irrodl.v18i7.3279.

Chan, L. (2005). WebCT revolutionized e-learning. UBC Reports, 51(7).

Church, K. \& de Oliveira, R. (2013). "What's up with WhatsApp? Comparing mobile instant messaging behaviors with traditional SMS." In Proceedings of the 15th International Conference on Human-Computer Interaction with Mobile Devices and Services (MobileHCI), Munich, Germany, pp. 352-361.

Choy, Susan. 2002. Findings from the Condition of Education 2002: Nontraditional Undergraduates. Washington, DC: National Center for Education Statistics.

http://nces.ed.gov/programs/coe/2002/analyses/nontraditional/index.asp

Corbin J, Strauss A. (2008). Basics of Qualitative Research: Techniques and Procedures for Developing Grounded Theory. 3rd ed. Thousand Oaks, CA: SAGE Publications; eds.

Creswell, J. W. (2014). Research design: Qualitative, quantitative, and mixed methods approaches (4rd ed.). Los Angles: Sage.

Earley, S. (2017). There's no AI (artificial intelligence) without IA (information architecture). IT Professionals 18(3). 58 - 64. Doi: $\underline{10.1109 / M I T P .2016 .43}$ 
Gronlund, Å., \& Islam, Y. (2010). A mobile e-learning environment for developing countries: The Bangladesh virtual interactive classroom. Information Technology for Development, 16(4), 244-259.

doi:10.1080/02681101003746490

Hudson, L. \& Ozanne, J. (1988). Alternative Ways of Seeking Knowledge in Consumer Research. Journal of Consumer Research, 14(4), 508-521.

Johnson, G. M. (2007). College student internet use: convenience and amusement. Canadian Journal of Learning and Technology, 33(1).

Joy Online (2013). Increase use of smartphones made Ghana No-1in mobile broadband penetration. Retrieved from: business.myjoyonline.com/pages/news/201301/99976.php

Jurado, R. G., Pattersson, T., Regueiro-Gomez, A. \& Scheja, M. (2014). Classification of the feature in learning management systems. XVII Scientific Convention on Engineering and Architecture, Havana City, Cuba, Nov 24th 28. Conference Paper.

Kathman, B. (2017). 3 biggest trends impacting higher education communication this year. Higher Education Technology: SignalVine. Retrieved on July 18, 2018, from: https://www.signalvine.com/higher-educationcommunication-trends/

Laary, D. (2016). Ghana: Mobile phone penetration soars to 128\%. The Africa Report. Retrieved from: www.theafricareport.com/West-Africa/ghana-mobile-phone-penetration-soars-to-128.html

Larkai, A. T., Ankomah-Asare, E. T. \& Nsowah-Nuamah, N. N. N. (2016). Distance education in Ghana: An overview of enrolment and programme patterns. Proceedings of INCEDI 2016 Conference, Accra, Ghana; 184 - 190.

Lincoln, Y., and Guba, E. (1985). Naturalistic Inquiry. London: Sage.

Löfgren, K. (2013). What is ontology? Introduction to the word and the concept. Examily. Retreived on July 14, 2018, from: https://examily.com/article/what-is-ontology-introduction-to-the-word-and-the-concept-10090

Moisey, S. \& Hughes, J. (2008). Supporting the Online Learner. In: Anderson, T. (Ed.), The Theory and Practice of Online Learning, 2nd ed., AU Press: Athabasca, Alberta, 419-432, 2008.

Motlik, S. (2008). Mobile learning in developing nations. Technical Evaluation Report. The International Review of Research in Open and Distance Learning, 63, 9(2). Retrieved from http://www.irrodl.org/index.php/irrodl/article/viewArticle/564/1039

National Center for Education Statistics (NCES, 2009). Total fall enrollment in degree-granting institutions by control and type of institution, age, and attendance status of student: Digest of Educational Statistics 2009. Table 192.2007. http://nces.ed.gov/programs/digest/d09/tables/dt09_192.asp?referrer=list

Neuman, L. W. (2000). Social research methods: Qualitative and quantitative approaches (4th Ed.), USA: Allyn and Bacon.

Pew Research Center Surveys (2015). Spring 2014 global attitudes survey: Q68. Retrieved from: www.pewglobal.org/2015/04/15/cell-phones-in-africa-communication-lifeline/

Quin, C (2001). mLearning: mobile, wireless, in-your-pocket learning. /L1 = LQH, Fall 2002.

Ross-Gordon, J.M. (2011). Research on adult learners: Supporting the needs of a student population that is no longer nontraditional. Peer Review, 13(1), 26-29.

Sener, J. (2015). Definitions of e-learning courses and programs version 2.0 April 4, 2015. Updated E-Learning Definitions. Available at: http://onlinelearningconsortium.org/updated-e-learning-definitions-2/

Shearer, R. (2011). The impact of mobile access on motivation: Distance education student perceptions. Penn State University World Campus.

Sloan Consortium. (2008). Staying the course: Online education in the United States. Wellesley, MA: Babson College.

Smith, S. D., Salaway, G., \& Borrenson C. J. (2009). The ECAR study of undergraduate students and information technology, EDUCAUSE Center.

Statista (2018). Most popular mobile messaging apps worldwide as of April 2018, based on number of monthly active users (in millions). The Statistics Portal. Available at: https://www.statista.com/statistics/258749/most-popularglobal-mobile-messenger-apps/

Tella, S. (2003). M-learning—Cybertextual traveling or a herald of Post-Modern education? In H. Kynäslahti \& P. Seppälä (Eds.), Professional mobile learning (pp. 7-21). Helsinki: IT Press. Retrieved from http://www.helsinki.fi/ tella/mlearningtella.pdf 
Koomson, W. K. (2018). Leapfrog Technologies: Can Mobile Technologies Compete Successfully With Traditional Learning Management Systems? Advances in Social Sciences Research Journal, 5(8) 234-250.

UNESCO (2013). UNESCO policy guidelines for mobile learning. Paris, France. ISBN 978-92-3-001143-7

Yeboah, J. \& Ewur, G. D. (2014). The impact of WhatsApp Messenger usage on students performance in tertiary institutions in Ghana. Journal of Education and Practice 5(6) 157-164. 